ИСТОРИЈСКИ ЧАСОПИС, књ. LXVII (2018) стр. 223-246

THE HISTORICAL REVIEW, vol. LXVII (2018) pp. 223-246

УДК: 316.42:94](497.11),,1861/1864“:929

\author{
Милан РАНЪЕЛОВИЪ ${ }^{*}$
}

Ниш

\title{
СПРОВОЂЕЊЕ ТАНЗИМАТА У НИШУ ЗА ВРЕМЕ МИДХАТ-ПАШЕ 1861-1864. ГОДИНЕ
}

\begin{abstract}
Ancmpaкm: Рад обрађује тему од великог значаја за истраживање јужног дела централне Србије у последњим деценијама османске власти над њим. Реч је о османском реформатору и политичару Ахмеду Мидхат-паши, који је за време управничког мандата у Нишу са успехом остварио низ пројеката преузетих из Западне Европе, користећи овај град као своју неформалну огледну средину. С тим у вези, у овом раду анализиран је допринос Мидхат-паше у решавању проблема социјалне, верске, инфраструктурне и комуналне природе, који су почетком шездесетих година XIX века ометали функционисање Ниша и отежавали суживот његовог хетерогеног становништва.
\end{abstract}

Кључне речи: Ахмед Мидхат-паша, Ниш, Османско царство, Танзимат, модернизација.

Политичке промене, до којих је у Османском царству дошло прокламовањем Гилханског хатишерифа (1839) и Ислахат фермана (1856), довеле су до еманципације његових немуслиманских становника, али и до појачаног антагонизма између њих и, до тада, привилегованих муслимана. Оба документа настала су у тренуцима политичке неотпорности Порте према утицају европских држава, које су на једнакости права свих османских поданика највише и инсистирале. Зато је спонтано усвајање новог курса државе међу традиционалистичким и конзервативним муслиманским круговима текло споро и тешко.

Део османске политичке елите сматрао је бесмисленим покушај да се османска држава изолује од спољашњег утицаја, видевши у томе прилику да својим развојем сустигне узоре у Западној Европи. Ту групу османских политичара након 1839. године чинили су поборници

*istok81@gmail.com 
Танзимата (1839-1876), покрета који је имао за циљ вестернификацију Османског царства. Његов зачетник био је Мустафа Решид-паша (1800-1858), велики везир у више мандата и сива еминенција османске политичке сцене прве половине XIX века.

Уз Решид-пашу стајао је читав низ државника и чиновника које су звали танзиматлијама (Tanzimatçi). ${ }^{1}$ Генерацијски, делили су се на оне које су предводили Решид-пашини политички штићеници Фуад-паша и Алипаша, и на оне који су дошли након њих, на челу са Ахмед Мидхат-пашом и Недим-пашом. Прва генерација након Решид-паше имала је политичку мисију да до краја спроведе његове идеје и постара се да остану дубоко инкорпориране у широки спектар институција Османског царства. На другој генерацији било је да настави вестернификацију државе на основама које је претходна генерација поставила, имплементира нове, крупније подухвате и да се носи са политичком опозицијом танзиматског покрета, која је од почетка друге половине XIX века већ била јасно формирана (висока улема, конзервативни друштвени слојеви, део политичке елите и чиновништва).

У првим деценијама XIX века расадник прогресивних османских политичара била је Преводилачка канцеларија (tercüme odas1) при Порти, где је већина водећих танзиматлија, попут Мехмед Решид-паше, Али-паше, Фуад-паше, Савфет-паше, Мухиф-паше и Намик Кемал-беја, провела део своје каријере. ${ }^{2}$ Кроз ову установу они су посредно (преко кореспонденције са европским владама и дворовима) и непосредно (кроз контакте са европским дипломатама у Цариграду) имали прилике да се упознају са политичким тековинама и трендовима у култури, науци и привреди западноевропских земаља. Све до 1839. године, тј. до прокламовања Гилханског хатишерифа, прозападно образовање танзиматлија махом се сводило на личну иницијативу и селективна интересовања појединца. Међутим, након 1839. године султан Махмуд II отворио је низ школа (Меkteb-i Ulum-i Edebiyye, Mektebi-i Maaraf-i Adliye) за образовање државног чиновништва по узору на оно у Западној Европи. ${ }^{3}$ Након Кримског рата (1853-1856) наставило се са систематским развојем оваквих установа. ${ }^{4}$

1 R. H. Davison, Reform in the Ottoman Empire 1856-1876, Princeton 1963, 37.

2 Иcmo, 29

3 S. A. Somel, The Modernization of Public Education in the Ottoman Empire, 18391908: Islamization, autocracy, and discipline, Leiden 2001, 34.

${ }^{4}$ И. Ортајли, Најдужи век империје, прир. и прев. М. Маринковић, Београд 2004,122 . Године 1856. у Османском царству основано је Министарство за јавно образовање, што је подстицајно деловало на повећање броја ускостручних образовних установа. 
Упоредо са тим, заживела је и пракса школовања османских стипендиста у Француској, Аустрији и осталим европским земљама. То је довело до тога да шири слојеви образованих Османлија буду упознати са тековинама развијене хришћанске Европе. Захваљујући свему томе, већ од седме деценије XIX века Танзимат више није био само мимикрија западњачких идеала којима су танзиматлије тежили, већ покрет чија је снага озбиљно утицала на основе шеријатом укалупљеног османског друштва. Другим речима, како је то описао Илбер Ортајли, организација државе је и са физичког аспекта стекла физиономију. ${ }^{5}$

Једна од тековина модернизације Османског царства по западноевропском моделу била је хуманизација односа међу његовим становништвом, што је посебно било тешко постићи у верски и етнички хетерогеним пределима Румелије. Такав је случај био са нишким ејалетом, пространим пашалуком који се граничио са Кнежевином Србијом. У периоду након завршетка Кримског рата (1853-1856) овај ејалет запао је у хаотично стање, услед отпора локалних власти да спроведу државне реформе, и лоших друштвено-економских односа. Два мандата лоше управе под Зејнел-пашом (1857-1860) и Осман-пашом (1860-1861) приморали су Порту да за Ниш нађе дуготрајно решење које ће стање у овом делу Османског царства поправити. С тим циљем, на место нишког мутесарифа био је постављен Ахмед Мидхат-паша.

\section{Ахмед Мидхат-паша}

Ахмед Мидхат-паша један је од највећих османских реформатора у XIX веку. Прво чиновничко искуство стекао је 1844. године, када је учествовао у спровођењу економских реформи у Сирији. Након успешно завршеног посла овде, постављен је за првог писара Великог државног већа. ${ }^{6}$ Пошто је већ тада уживао репутацију ефикасног и некорумпираног чиновника, био је послат 1852. године на Левант да истражи Портине сумње у проневеру царинског новца. Сумње су се показале оправданим, а за кривца означен је тадашњи заповедник Арабијског корпуса Мехмед Еминпаша Кибризли. ${ }^{7}$ То је између Мидхат-паше и Кибризлија створило дубоко и трајно непријатељство. У међувремену, учествовао је у пацификацији

${ }^{5}$ И. Ортајли, Најдужи век империје, 126.

6 A. H. Midhat, The life of Midhat Pasha; a record of his services, political reforms, banishment, and judicial murder, London 1903, 32.

7 Исто, 33. 
хришћанског незадовољства у Силистријском и Видинском санџаку после окончања Кримског рата (1853-1856), након чега је отишао на шестомесечно путовање по Западној Европи и обишао велике метрополе. Овде су на њега оставили снажан утисак полетни резултати парне револуције, те ће након повратка у Османско царство бити енергичан заговорник усвајања добре праксе из развијених европских земаља.

У Османско царство вратио се за време мандата Мехмед Еминпаше Кибризлија на месту великог везира, те га је Кибризли, због ранијих сукоба, именовао за управника нишког ејалета (1861), румелијске области која је почетком шездесетих година XIX века била пред колапсом због лоше управе претходних деценија. ${ }^{8}$

Постигавши велики успех на овом положају, Мидхат-паша је након тога био постављен за првог управника експерименталне области Дунавски вилајет (1864-1868), где је имао за циљ да реализује искуства из Ниша и преузете пројекте из Западне Европе. Формирање Дунавског вилајета и накнадна подела Османског царства на вилајете, као највиша територијално-административна тела у провинцијама, извршени су према два закона на чијој је изради у јесен 1864. године учествовао и Мидхатпаша, као један од најуспешнијих управника османске провинције у то време. ${ }^{9}$ Након тога уследиле су службе на месту председника Правног већа Османског царства и управника Багдадског вилајета (1868), Једренског вилајета (1872), министра правде у два мандата и управника Солуна, све у периоду 1872-1875. године. Високом политиком наставио је да се бави, заговарајући идеју стварања првог османског устава. До обнародовања овог документа дошло је 23. децембра 1876. године, за време Мидхатпашиног мандата на месту великог везира. Међутим, како је у међувремену дошло до смрти бившег султана Абдулазиза, великог противника устава, његов наследник Абдулхамид II и део конзервативне јавности сматрао је кривцима Мидхат-пашу и круг политичара окупљених око њега. ${ }^{10}$ Године 1881. Мидхат-паша је званично био оптужен за учешће у убиству султана Абдулазиза, те је у конструисаном политичком процесу и осуђен за ово дело. Због притиска јавности и страног дипломатског кора, смртна казна му је била преиначена у доживотно прогонство, те је последње године живота провео у тврђави Ал Таифа, на Арабијском полуострву, где су заједно са њим били затворени и остали осуђеници у овом процесу. Након

${ }^{8}$ Царски распояжденія, Цариградскй въстникъ (18. фебруарій 1861) 32.

9 Т. Бакръджиева, На крачка пред времето. Държавникът реформатор Мидхат nama (1822-1884), Pyce 2009, 51.

${ }^{10}$ A. Wink, Al-hindi: The Making of the Indo-islamic World, 1, Leiden 1996, 1032. 
смиривања тензије и губитка интересовања јавности за овај догађај, 8. маја 1884. године, Мидхат-паша и остали завереници погубљени су у Ал Таифи по наређењу Абдулхамида II. ${ }^{11}$ Тек 1951. године Мидхат-паша је постхумно рехабилитован од оптужбе за регницид, а његови земни остаци враћени су у Турску са великим почастима. ${ }^{12}$

Мидхат-паша је спадао у видљиву, али не и нарочито бројну групу либерала међу танзиматлијама. Другим речима, за њега вестернификација није била само решење за проблеме Османског царства који су се нагомилали током XIX века, већ врста препорода који је османској држави могао да обезбеди сигурну будућност и шансе за даљи развој. ${ }^{13}$ Као један од најважнијих корака у том процесу Мидхат-паша је препознао стабилан однос између централне власти и провинцијске управе. Како је ова потоња чешће подложна негативним утицајима и мањкавостима у раду, развој локалних установа које су је чиниле за њега је био важан предуслов за функционалан однос провинције и централне власти, самим тим и за напредак државе. ${ }^{14}$

\section{Војно уређење}

У Нишу се током XIX века осећало снажно војно присуство Османлија, због пограничног положаја града који је то наметао. Зато је улога османског гарнизона у Нишу најчешће била да спречава хајдучију, упаде оружаних група из Србије и погранични шверц.

Овакве обавезе нишког гарнизона утицале су на пад дисциплине у његовим редовима, те је дошло до појава типичних за све војске XIX века које су биле у мирнодопском стању - доконост, корупција, пијанство, честа шенлучења, туче и конфликти са локалним становништвом. Све ово заједно отежавало је контролу над градом. ${ }^{15}$ Због тога је један од

${ }^{11}$ R. H. Davison, Midhat-pasha, Encyclopaedia of Islam, VI, Leiden 1991, 1034.

${ }^{12}$ Исто, 1035.

${ }^{13}$ И. Ортајли, Најдужи век империје, 230. Због тога Ортајли танзиматлије дели на либерале и либералисте, убрајајући Мидхат-пашу у ове прве.

${ }^{14}$ Исто, 137.

${ }^{15}$ Историјски архив Ниш, Старе и ретке књиге, Мидхат-пашини мемоари (превод Оријенталног института, документ без сигнатуре), Сарајево 1953, 2 (= ИаН, Мидхат-пашини мемоари). Политичка биографија Мидхат-паше коју је објавио његов син Али Хајдар Мидхат постоји у две верзије. Једна је објављена у Лондону на енглеском, а друга у Цариграду, на османском турском језику. Превод из Историјског архива Ниш који смо овде користили потиче од верзије на османском 
првих задатака Мидхат-паше у Нишу био уређење војног стања нишког гарнизона.

Један од најочигледнијих проблема који је имао нишки гарнизон био је недовољан број зграда за смештај. Војници су због тога закупљивали собе по сарајима и хановима, при чему су контакт са цивилима и лихварство крчмара-станодаваца често били разлози за изгреде војника. Како би томе стао на крај, паша је одлучио да обезбеди смештај за војску и изолује је од цивила. Тако је 1861. године започета изградња Нове касарне испод брда Бубањ у југоисточном делу Ниша. Кулуком локалног становништва, приватним донацијама и средствима државе касарна је била завршена за шест месеци. ${ }^{16}$ Чинила ју је велика камена зграда која ће након 1878. године послужити српским властима да под Бубњем формирају велики комплекс српске војске. Након што је здање изграђено, а војска смештена у њу, смириле су се тензије у граду, што се одразило на свакодневицу његових житеља.

По завршетку касарне, извршени су радови на ојачању караула на бедемима тврђаве у Нишу. Повећање одбрамбене моћи града није се вршило само у његовом средишту, већ и на ободима. Како је Ниш имао две ризичне тачке за одбрану, брда Виник и Горицу, Мидхат-паша је наредио

турском језику. Период који је Мидхат-паша провео у Нишу у обе верзије описан је прилично скромно, на свега две или три странице; штавише, у верзији на енглеском језику приређивач је Мидхат-пашину службу у Нишу описао афирмативно, док је више пажње посветио његовом раду са позиције великог везира и министра. Разлог за то је свакако чињеница што је верзија на енглеском језику требало да има знатно шири круг читалаца, па је стога и више пажње посвећено пашином учешћу у догађајима од већег међународног и дипломатског значаја који су у Европи могли лакше да се прате (за разлику од оних који се тичу унутрашње, прилично локалне османске политике). Ова верзија пружа и прегледнији увид у политичку каријеру Мидхат-паше. Верзија на османском турском је детаљнија, када је у питању служба Мидхат-паше у Нишу. У њој су са нешто више пажње описани проблеми са којима се паша у Нишу сусрео, као и решења која је применио за њихово уклањање. Међутим, ни она не открива нарочито значајне детаље када су у питању, на пример, локални топоними које бисмо могли да доведемо у везу са пашином грађевинском или комуналном политиком у овом граду и његовој околини. Нема података о финансијском обиму његових подухвата нити се помињу имена политичких ауторитета и представника локалних заједница на чију је сарадњу свакако морао да буде упућен. Зато смо у раду користили обе верзије, како би се кроз њихово узајамно допуњавање препознала веза у пракси коју је Мидхат-паша применио у свом раду пре доласка у Ниш, за време боравка у њему и након одласка из њега, на више и одговорније положаје.

${ }^{16}$ ИаН, Мидхат-пашини мемоари, 1. 
да се поред већ постојеће мреже табија на Горици саграде додатне на Винику, и тиме у потпуности затвори артиљеријски домет граду. Виничку мрежу табија чинило је њих четири, од којих је једна, названа по Мидхатпаши, била најјача. Касније, током српске опсаде Ниша у децембру 1877. године, овај положај био је много укопанији и утврђенији од горичког, те су га Срби савладали тек када је исфорсирана јака артиљерија.

Последња ствар из војног домена коју је Мидхат-паша уредио у Нишу била је изградња војног конака код Ћеле-куле. Овај конак био је намењен за османске официре који су добили прекоманду у Ниш, а у прво време нису имали решено питање приватног смештаја.

\section{Саобраћај}

Ниједан фактор није тако био заслужан за просперитет Ниша као што је то његов положај на Цариградском друму. Као природна тачка на прелазу између западног и централног Балкана, Ниш је био граничник између моравске и вардарске регије. Нову етапу развоја своје привреде доживео је доласком Османлија у XIV веку, када се надовезао на већ разрађену саобраћајну мрежу њиховог царства. Тиме су, макар технички, удаљени центри на Истоку постали доступни његовим трговцима и обратно.

Супротно од великих путних артерија, локална саобраћајна мрежа нишког краја била је неразвијена, на шта је у великој мери утицала хајдучија у залеђу овог града. Ње је било на сваком друму на коме би се осетило слабо присуство војске, те је локална власт била приморана да је сузбија учесталим војним патролама у залеђу. Хајдучија у нишкој околини углавном није имала озбиљне размере, али је била довољно присутна да подстакне несигурност код путника и каравана на друму.

Уређење путева је први подухват Мидхат-паше у Нишу. ${ }^{17}$ Имао је три етапе: оспособљавање деоница Цариградског друма које су повезивале Ниш са осталим центрима на Балкану, његово повезивање са суседним варошима и повезивање Ниша са његовим залеђем. ${ }^{18}$

${ }^{17}$ М. Ђ. Милићевић, Краљевина Србија, Београд 2006, 161; ИаН, Мидхат-naшини мемоари, 1. Након што их је Мидхат-паша уредио, транспорт робе на нишким путевима био је ушестостручен. Конкретан пример наведен је у његовој биографији, где стоји да се путем, на коме је сто педесет ока робе транспортовано три дана, након трасирања и уређења могло да се пребаци пет стотина ока робе за свега један дан.

${ }^{18}$ С. Андрејевић, Аграрни односи и производюа у околини Ниша пред ослобођење од Турака, Нишки зборник 9 (1980) 31. 
Од међуградских подухвата највећи су били трасирање линија које су водиле до Скопља, Видина (преко Белоградчика) и Софије. Рад на повезивању са Софијом започет је 1861. године и, као резултат, свео је путовање имеђу Ниша и Софије на тридесет сати, што је у то време био велики успех. ${ }^{19}$ Након тога, уређена је траса од 155 километара која је водила до Видина. Ова је била започета 1862. године, али је због потешкоћа на терену завршена тек 1868 . године. ${ }^{20}$ Посебна отежавајућа околност овог подухвата био је стратешки положај, због близине српске границе, па се током изградње пазило на њено избегавање, као и на превазилажење природних препрека. Мрежа до Скопља покривала је правце који су водили и до Лесковца, Врања, Приштине и Куманова. ${ }^{21}$ Лесковац је на овом путу имао посебан значај, пошто је војна подршка која је у првој половини XIX века стизала из њега била од пресудног значаја за очување Ниша.

Магистрални радови нису вршени само у правцу југ-југоисток, већ и ка северу, тако да је обновљена и веза Ниша са Прокупљем. Независно од подухвата везаних за Ниш, Мидхат-паша је у исто време предузео и низ мањих интервенција којима су Власина, Пирот и Врање повезани са својим залеђем. ${ }^{22}$

Током свих ових радова поклоњена је пажња функционалности релација, па су поред радова на путевима грађени и мостови на местима где су били неопходни. Међу њима највећа су била два моста на Морави код нишких села Чечина и Мрамор. Први је подигнут на девет камених стубова и био је дуг 150 метара, а широк 8,5 метара, док је мраморски мост имао такође камене стубове, али је био нешто краћи, око 129 метара и широк седам метара. ${ }^{23}$ Посебна занимљивост биле су мере које је нишки управник предузео како би путовања појединим трасама учинио угодним. На траси од једанаест километара пута који је преко Јелашнице водио од Ниша за Пирот наредио је да се засаде тополе. ${ }^{24}$ Намера је била да мирис и хлад ових стабала учине путовање нарочито пријатним. Поред ове трасе, као посебно погодан помиње се и Врежински пут који је од овог приградског насеља водио до Ћеле-куле. ${ }^{25}$

\footnotetext{
${ }^{19}$ ИаН, Мидхат-пашини мемоари, 1.

${ }^{20}$ Ф. Ф. Каниц, Срби и становништво, II, Београд 2007, 196.

${ }^{21}$ Б. Андрејевић, Мидхат пама, Енциклопедија Ниша - историја, Ниш 1995, 155.

${ }^{22}$ М. Милићевић, Кралевина Србија, 162, 333.

${ }^{23}$ Ф. Ф. Каниц, Срби и становништво, 176, 192.

${ }^{24}$ Исто, 185.

${ }^{25}$ Исто, 181.
} 
Како би се проток робе до Ниша и из Ниша равномерно одвијао, упоредо са обновом међуградских линија, Мидхат-паша је радио на уређењу главних градских артерија: поплочаване су саобраћајнице, уређене и разграничене махале.

Подстакнувши градску привреду уређењем путева, Мидхат-паша је основао Шпедитерску компанију за превоз робе и путника. Рад ове организације био је најбољи лакмус по коме се видело приходовање од нових путева. ${ }^{26}$ Компанија је коњском запрегом вршила промет робе и путника ка Београду, Скопљу, Приштини и Софији и није бележила негативно пословање.

Тек по завршетку наведених подухвата прави обртнички потенцијал Ниша је дошао до изражаја. ${ }^{27}$ Међутим, осим веће фреквенције трговања и превоза, сврха нових путева била је да среди дотадашње пореско стање које је настало током педесетих година XIX века, услед експанзије читлуксахибија у Нишком санџаку. Њима је уочи Мидхат-пашиног доласка у Ниш становништво дуговало око десет милиона гроша ${ }^{28}$. Изградњом нових путева олакшан је приступ селима, па је постојала шанса да се бар део ових дуговања наплати. Поред тога, и дуговања према држави могла су лакше да се убиру, па је наплата пореза скоро редовно вршена. Са друге стране, нови путеви су сеоском становништву били важни, јер су олакшали одлазак до њива и парцела са којих су убирани плодови и одношени у нишку чаршију на пазар.

Тактичност у ревитализацији важних путева довела је до акумулације пара у народу и градској каси. То је олакшало покретање нових грађевинских иницијатива без значајнијих финансијских напрезања државе и локалног становништва.

\section{Менафи-сандук}

Ова институција основана је 1864. године, након процене Мидхатпаше да је Ниш способан за самосталне пројекте без већих осцилација у

\footnotetext{
${ }^{26}$ Б. Андрејевић, Арабаиијска компанија, Енциклопедија Ниша - историја, Ниш $1995,10$.

${ }^{27}$ ИаН, Мидхат-пашини мемоари, 1. У вези са овим, у Мидхат-пашиној биографији нарочито се помиње извоз вина из нишког краја, који је био богат виноградима, на тржишта у Солуну, Пловдиву и Битољу (Манастиру).

${ }^{28}$ ИаН, Мидхат-пашини мемоари, 1.
} 
градском буџету. ${ }^{29}$ Замишљена је била као порез који се имао убирати у циклусу од осам година. Првих пет година је на њега одлазила додатна половина свих дажбина које је појединац дуговао држави, а у наредне три године овај износ је требало да се сведе на једну четвртину државних намета. $^{30}$ Карактеристика ове дажбине била је њена прилагодљивост платежним средствима порезника, тако да је могла да се подмири и у натури. У том случају, роба опорезованог лица је продавана, а новац од њене продаје стављан у касу, тј. сандук. Заузврат је опорезовано лице имало права да из ове касе узме кредит по променљивим, али врло повољним условима.

Средства која је менафи-сандук акумулирао од самог оснивања била су значајна. Претпоставља се да је већина пашиних радова из 1864. године, међу којима је био и наставак изградње Саборног храма у Нишу, финансирана из ње. Две године након тога сандук је располагао сумом у еквиваленту од 339.004 тадашњих српских динара. ${ }^{31}$

Ова институција наставила је несметано да ради и након 1878. године. Нове српске власти преузеле су је и разрадиле, тако да су средствима из ње у Нишу подигнути водовод, гимназија, пољопривредна станица и амбуланта у Заплању (1909). ${ }^{32}$ И у Османском царству настављено је са применом овог система. После Ниша менафи-сандук био је формиран и у другим крајевима османске државе. Мидхат-паша је 1867. године саставио Регулативе Националног фонда по начелима овог система, те је разрадом једног његовог дела 1888. године формирана Ziraat Bankasi. ${ }^{33}$

\section{Болница}

Преко менафи-сандука и наплатом заосталих државних потраживања подигнут је низ мање или више важних здања у Нишу. Једно од њих била је болница код Ћеле-куле.

Ова болница представља језгро данашње Војне амбуланте у насељу Трошарина. Средином XIX века овај потез био је градска периферија,

\footnotetext{
29 Љ. Соколовић, Паре из Менафи-сандука за нишку гимназију и водовод, Нишки весник 19 (2002) 2.

${ }^{30}$ Исто, 2.

31 Љ. Соколовић, Паре из Менафи-сандука, 2.

${ }^{32}$ Иcmo, 2.

${ }^{33}$ H. Inalcik, D. Quartaert, An Economic and Social History of the Ottoman Empire, 2, Cambridge 1994, 872.
} 
чиме је постигнута изолација болнице од остатка града. Здање није било нови објекат подигнут из темеља, већ адаптирани конак са почетка XIX века, који је припадао некадашњем нишком управнику Хафис-паши. ${ }^{34}$

Болница је била једноспратна камена зграда, у којој је било осамдесет лежајева. Била је дуга и отворена, са пуно прозора, као што су у Танзимату широм Румелије подизана многа здања за боравак људи. Није сигурно колико је са овако скромним капацитетом могла да подмири потребе локалне популације, али је хигијена у њој била на високом нивоу, што Милићевић налази необичним за тадашње Османлије. ${ }^{35}$ По ослобођењу Ниша уз болницу су дограђена још три павиљона, тако да је представљала својеврсни војни здравствени центар.

\section{Ћеле-кула}

Поред болнице и официрског конака на Трошарини, Ћеле-кула, која се налази у овом делу Ниша, такође је била предмет Мидхат-пашиног интересовања. Како је и у његово време била симбол османске доминације у Нишу, отежавала је превазилажење јаза између муслимана и хришћана у овом граду. Осим тога, бројни западноевропски пролазници кроз Ниш документовали су је у својим путописима, што је у Европи само јачало слику о Османлијама као варварима са Истока. ${ }^{36}$ Другим речима, ово здање представљало је сушту слику негативног османског наслеђа на Балкану, док је Танзимат управо имао за један од главних циљева да овакву перцепцију османског друштва отклони.

Због свега тога, Мидхат-паша је 1861. године покушао да уклони Ћеле-кулу, али је дошло до озбиљне реакције нишких муслимана, због чега је морао од тога да одустане. ${ }^{37}$ Како би делимично умањио њен упадљив изглед, наредио је да се лобање из ње уклоне и додатно је пацификовао изградњом мале чесме испред ње. ${ }^{38}$ На тај начин, Ћелекула је чесмом, болницом и официрским конаком физички делимично

\footnotetext{
${ }^{34}$ Историја Ниша, 1(= ИН 1), Ниш 1983, 238 (Р. Тричковић).

${ }^{35}$ М. Милићевић, Краљевина Србија, 106.

${ }^{36}$ Алфонс де Ламартин (1833), Жером-Адолф Бланки (1841), Јегор Петрович Ковалевски (1843-1844) итд.

${ }^{37}$ М. Милићевић, Краљевина Србија, 78.

${ }^{38}$ В. Ђорђевић, Успомене, прир. С. Слапшек, Београд 1988, 115-116; Б. Ловрић, Историја града Нима, Ниш 1927, 58. Ловрић тврди да су по ослобођењу Ниша у Ћеле-кули нађене свега три лобање.
} 
била сакривена од пролазника. Ипак, то није нарочито утицало на пад интересовања страних намерника за њу.

\section{Насипи, махале и улице}

Комунално и урбанистичко стање је у Нишу, као и код већине османских градова, представљало велики проблем. Под овим се мисли на неплански подигнуте стамбене и јавне објекте, што је условљавало развој саобраћаја у граду и његово често закрчење. Сокаци су били уски и једва проходни од столица које су размештане испред ашчиница, кафана и дућана. На нишким сокацима запрежна кола нису могла да се мимоиђу, а свако закрчење било је праћено конфликтима и виком пролазника и трговаца. Осим тога, испред касапница и берберница увек је било прљавштине и бара, што је у неосунчаним и непроветреним сокацима увек био извор заразе. ${ }^{39}$

Због свега тога Мидхат-паша је започео уређење Ниша одмах по свом доласку. На уређењу канализације радило се упоредо са пресецањем махала, које су се дотад развијале спонтано, без икаквих уредби и прописа. Склоњени су тремови, чардаци и надстрешнице које су угрожавале пролазнике и уклоњен је шут који је закрчавао главне артерије. Када је омогућена већа проходност главних траса, паша је наредио њихово проширење, како би се олакшао пролаз трговцима. ${ }^{40}$ Мањкавост овог подухвата била је та што су ови радови вршени само на најбитнијим градским потезима, док је у махалама стање било скоро непромењено. И сокаци који су водили до Саборног храма били су изузети од ових санација. $^{41}$

Једини радови у махалама били су њихово узајамно разграничење. Тиме је постигнута боља прегледност града и олакшано је стварање карантина, уколико би се у некој од махала запатила која болест.

Насипи, који су прошарали град, чинили су два прстена од којих је спољашњи, који никада није био завршен, ишао потезом данашње Улице војводе Танкосића до раскрснице између Улице Филипа Кљајића и 7. јула, одакле је водио до тврђавског моста, тј. воденице која се налазила

\footnotetext{
${ }^{39}$ М. Милићевић, Краљевина Србија, 101-103.

40 J. Ћирић, Јаркови, претече канализащије и водоводног система, Нишки весник 1 (1999) 17.

41 Ж. Живановић, Ниш и нишке знаменитости, прир. Г. Максимовић, М. Ракоција, Ниш 2004, 59-60.
} 
тик уз њега. ${ }^{42}$ На сваком крају овог прстена налазио се један од прелаза, којих је укупно било четири. Није позната мрежа унутрашњих насипа, али је скоро сигурно да нису залазили дубоко у махале. Сматра се да су поред комуналне, ови насипи имали и стратешку важност, пошто су на прелазима преко њих биле размештене стражарнице, чиме је контролисан улаз и излаз у варош. ${ }^{43}$ По ослобођењу од Османлија, српске власти су извршиле засипање ових насипа, како би их искористили за трасирање нових градских улица.

У мање значајна здања која је Мидхат-паша подигао или обновио спадају мехзилхана и хапсана у тврђави. ${ }^{44}$ Ова последња била је заправо надоградња старије хапсане која је подигнута за време изградње тврђаве (1719-1723). Надоградња је извршена 1864. године, а здање је, као и већина Мидхат-пашиних зграда, било од цигле и камена. ${ }^{45}$ Хапсана је имала пет ћелија и две просторије за жандаре у приземљу, док је на спрату било осам ћелија и две собе за болеснике. ${ }^{46}$

\section{Ислахана}

Сви јавни радови које је Мидхат-паша предузео били су преко потребни локалном становништву. Међутим, посебношћу једног пројекта, Мидхат-паша се доказао као администратор који је озбиљно схватао социјалне потребе заједнице на чијем је челу био. Реч је о васпитном дому - ислахани.

Мидхат-пашина идеја за подизање ислахане потекла је из његовог познавања француске културе, која му је била врло блиска. До његовог директног контакта са њом дошло је после сламања народног покрета у Бугарској након Кримског рата, у чему је Мидхат-паша учествовао (1856). Након смиривања нереда у Бугарској, Мидхат-паша је отишао у обилазак европских метропола, при чему је неко време провео у Француској. ${ }^{47}$ Сматра се да је ову прилику искористио да научи пуно о уређењу француског друштва и администрацији ове државе. Зато је ислахана била слична политехнама које су осниване у Француској још у

42 Ј. Ћирић, Јаркови, 17.

43 Ж. Живановић, Нии и нишке знаменитости, 59-60.

${ }^{44}$ Б. Андрејевић, Зграда затвора-хапсане у Тврђави, Енциклопедија Ниша историја, Ниш 1995, 84.

${ }^{45}$ Б. Андрејевић, Споменищи Нима, Ниш 2001, 82.

${ }^{46}$ Исто.

${ }^{47}$ Б. Андрејевић, Стари записи о Нишу (од V до ХІХ века), Ниш 1997, 137. 
XVII веку. Карактер тих школа био је социјални, колико и образовни, те је због тога ова врста школе била лако прихватљива у Османском царству.

Ислахана је подигнута 1862. године. Пре њене изградње, на земљишту где је подигнута налазило се турско гробље које је захватало површину данашње гимназије Стеван Сремаи/Бора Станковић и Основне школе Вожд Карађорђе. Цео комплекс избијао је на Пиротски сокак (Вождова улица), део Цариградског друма који је паралелно са левом обалом Нишаве пресецао Ниш. ${ }^{48}$ По пореској категорији била је вакуф. ${ }^{49}$ Пролазници кроз Ниш су је објашњавали онако како су је лично схватали; са̂м Мидхат-паша замислио ју је као васпитни дом за децу свих вера која су била сирочићи или остала незбринута. ${ }^{50}$ Ислахана је у исто време била азил за децу без дома (сиротиште), занатска школа и амбуланта. Имала је своје предаваче-занатлије који су преподне држали часове, а поподне практичну наставу кожарског, терзијског и обућарског заната. ${ }^{51}$ Деца су била подељена у разреде, а после одређеног времена проведеног у дому, полагала су квалификационе испите. Средства за одржавање ислахане обезбеђивана су градским парама, али је убрзо развијена мрежа добротвора, те је и број полазника почео да расте. Успех овог социјалноваспитног пројекта био је велики. Османска штампа ју је окарактерисала као прву модерну занатску школу у царству, што је био велики успех за град који до тада није имао ниједну сличну установу. ${ }^{52}$

Ислахану је чинила једноспратна зграда зидана каменом. У њој је била тридесет једна соба на спрату и седам радионица у приземљу. Нажалост, иако је дуго имала по стотинак полазника, ова институција није успела да заживи. Од ослобођења (1878), све до 1882. године, у њој је била смештена српска војна болница. Пошто је у том периоду здање претрпело велика оштећења, од 1882. до 1884. године у њој је био смештен обичан војни магацин. ${ }^{53}$ Како је губило од своје првобитне функције, тако је опадала и брига о овом здању, те су последње године његовог постојања везане за лоше хигијенске услове, због којих је на крају и спаљено (1885). Двадесетак година након тога, на њеним темељима подигнута је Прва нишка гимназија. За разлику од ислахане, она није била вишенаменска, али је по користи коју је донела Нишу убрзо превазишла свог претечу.

\footnotetext{
48 Ј. Ћирић, Ислахана, Нишки весник 5 (2000) 14.

${ }^{49}$ Б. Андрејевић, Споменици Нима, 206.

${ }^{50}$ ИаН, Мидхат-пашини мемоари, 2.

${ }^{51}$ ИН 1, 325 (Ђ. Игњатовић).

52 J. Ћирић, Ислахана, 14; М. Ристић, Историја града Ниша, 2, Београд 1934, 104.

53 В. Станојевић, Историја српског војног санитета, Београд 1992, 170.
} 


\section{Мухаџири}

Након инцидента на Чукур-чесми у Београду (1862), међународног притиска и у стрепњи за безбедност муслимана у Београду и Србији, Порта је била приморана да пристане на исељавање муслимана из унутрашњости Србије. Један део београдских муслимана-избеглица (мухаџира) био је примљен у Ниш.

Кретања становништва у Нишу и околини нису била везана само за долазак новог становништва, већ и за одлазак старог. Период од двадесет година, који је почео великом Нишком буном (1841), а завршио се истрагом великог везира Мехмед Емин-паше Кибризлија (1860), приморао је хришћане у Нишу да озбиљно размотре свој опстанак у овом граду. ${ }^{54}$ Прилика за одлазак указала се после истраге великог везира, када је притисак власти привремено попустио. Користећи смену паша у Нишу која је уследила, велики број Срба из овог града и његове околине прешао је у Србију (1860). ${ }^{55}$

Као новопридошли управник Нишког пашалука, Мидхат-паша је схватио да хришћани још увек нису имали поверења у њега, па је у вези са одливом становништва чинио једино што је у том тренутку могао. У намери да хришћане индиректно одврати од исељавања, издавао је административне пропуснице за то. Оне нису битније утицале на тренд исељавања ни тада нити у наредним годинама. ${ }^{56}$ Догађај на Чукурчесми само је убрзао ова кретања, тако да су од тада ове тихе миграције попримиле облик спонтане размене становништва - хришћана из Нишког пашалука и мухаџира из Србије. ${ }^{57}$

Појава муслиманских досељеника није започела доласком мухаџира из Србије 1862. године. Први талас мухаџира који су дошли у Ниш били су Татари са Крима, одакле су их Руси истеривали након окончања Кримског рата. Иако њихова миграција није директно погодила Ниш, већ градове у Бугарској, присуство Татара у Нишу било је евидентно, што је

${ }_{54}$ В. Чубриловић, Одабрани историјски радови, Београд 1983, 531.

${ }^{55}$ С. Андрејевић, Аграрни односи и производња у околини Ниша пред ослобођење од Турака, 36.

${ }^{56}$ Исто, 36; S. Dursun, Population policies of the Ottoman state in Tanzimat era: 1840 1870, Istanbul 2001, 4. Једно од првих начела за која су се залагали реформатори у Танзимату било је осигурање опстанка и повећање броја становништва. Овај задатак био је посебно битан у Румелији, која је у првој половини XIX века на један километар квадратни имала свега двадесет становника.

${ }^{57} \mathrm{~V}$. Baser, Turkish cultural memory in Balkans. Ironic accounts of the migrations to Anatolia, Bucharest 2006, 27. 
утицало на још већу хетерогеност муслиманске заједнице у овом граду. За време Мидхат-паше досељавање Татара се благо повећало. Каниц је забележио њихово присуство на источном излазу из Ниша, на путу ка Пироту и Белој Паланци. Поред Каница, остали извори наводе да је на истој локацији где су насељени Татари било насеље Черкеза. ${ }^{58}$ Њих је у Ниш 1862-1863. године из Бугарске довео њихов бег Асан. Завршетак Кримског рата такође је био разлог за исељење Черкеза са Крима, те је 300.000 њих кренуло пут Бугарске, уз координацију и помоћ локалних османских власти. ${ }^{59}$ Њихов долазак у западну и централну Румелију Порта је искористила за стварање тампон зона, услед могућих напада Србије са севера. Део ових Черкеза био је насељен у широком појасу на српско-османској граници, при чему је циљ овог насељавања био изолација српског живља у Румелији од Србије, али и повећање присуства муслимана на граници.

Долазак Черкеза у Ниш тешко је пао локалним хришћанима. Како би им решио егзистенцијално питање, Мидхат-паша је наредио подизање нове махале на простору данашњег Клиничког центра, у коме ће черкеске избеглице живети. За изградњу овог насеља ангажовани су били хришћани. Осим кулука, били су у обавези да обезбеде новац и кућне потрепштине које су биле неопходне њиховим новим суграђанима. Тако је формирано черкеско насеље од стотинак кућа, са једном касапницом и кафаном. Насеље је имало и џамију, која је била подигнута на месту данашње котларнице Клиничког центра. ${ }^{60}$ И поред величине ове колоније, Черкези нису постали битнији фактор у Нишу. Због својих скиталачких навика, убрзо су распродали све што им је држава обезбедила, па је већина њих асимилована са домаћим муслиманима или прешла у доњи, сиромашни слој муслиманске заједнице у Нишу.

Скоро под истим условима извршене су припреме за насељење мухаџира из Србије који су дошли у Ниш. У овом случају Мидхатпаша је водио рачуна о контакту нишких хришћана са београдским муслиманима, који су због присилног исељења из Србије били кивни на хришћане. Зато је за оснивање новог насеља одредио подножје брда Горица, у коме се налазила урушена џамија, некадашња Црква Светог Николе. Њеном обновом, у новој махали створено је језгро око кога ће се ${ }^{58}$ ИН 1, 311 (В. Стојанчевић). Татара је 1861. године било у двадесет пет кућа, а 1864. године Черкеза у четрдесет једној кући.

${ }_{59}$ Р. Мантран, Историја Османског ияарства, Београд 2002, 589-590; В. Чубриловић, Одабрани историјски радови, 530.

${ }^{60}$ М. Жупањевац, Черкеска махала, Енциклопедија Ниша - историја, Ниш 1995, 325 . 
новопридошли муслимани окупљати. Поред тога, горичка махала била је привлачна муслиманима и зато што се налазила иза хришћанске махале на Палилули, која је одвајала Горицу од вароши. Населивши муслимане у залеђе хришћанима, паша је хтео да се осигура од могуће усиљености хришћана због најаве изградње школе и Саборног храма у палилулској махали. Обе новоосноване махале успешно су завршене, с тим што је горичка била чистија и уређенија од черкеске. ${ }^{61}$

\section{Однос према хришћанима у Нишу}

Најкомплекснији део Мидхат-пашиног мандата у Нишу био је његов однос према хришћанима. Пашини поступци у највећем броју случајева хришћане у Нишу затицали су без става, пошто су у пограничној области, каква је био Ниш, политичке иницијативе народа скоро увек креиране под условима које су диктирали спољашњи фактори (у овом случају суседна Србија). Пашин однос према хришћанима одступао је од традиционалног стереотипа о односу паше и рајетина. Међутим, све добро што је учинио за хришћане у Нишу не треба приписати његовој бризи о њима, већ његовој проницљивости којом је откривао и уклањао проблеме који су кочили нормално функционисање заједнице на чијем је челу био.

Док са муслиманима никада није имао озбиљних проблема, сарадњу са хришћанима паша је морао да прикрива поступајући увек у сфери јавног и општег. И сами нишки хришћани (посебно Срби и Грци) често су имали сложен инертни однос, јер су се на њихов суживот свакодневно и непредвидљиво одражавале све привредне и верске интеракције ових народа у Османском царству. Због тога је Мидхат-пашина реакција често била условљена тренутком. ${ }^{62}$

Због овако компликованог стања, већина пашиних поступака према њима носила је у себи одређену дозу дволичности. У пракси се то видело кроз његове доброчинитељске посете школама (које су заправо биле инспекције), у награђивању савесних грађана и олакшавању хришћанима да ступе у брак (што је била далекосежна политика са циљем увећања пореских обвезника). ${ }^{63}$ На ове његове поступке надовезују се и конкретна дела која су била видљива у граду.

${ }^{61}$ Ф. Ф. Каниц, Срби и становниттво, 151.

62 Ж. Живановић, Ниш и нишке знаменитости, 58.

${ }^{63}$ ИаН, Мидхат-пашини мемоари, 2. Нажалост, нема обимнијих података о овом питању, које бисмо могли сматрати и једним од најзначајнијих који се помињу 


\section{Школа и школство}

Просветне прилике у Нишу шездесетих година XIX века могу се посматрати са два аспекта. Један је стање културе међу балканским народима унутар Османског царства, а други однос османских власти према Србији, као све наметљивијем културном центру на Балкану.

Што се тиче просветитељства, 1840. године започето је комерцијално штампарство у Османском царству, чиме је његова политичка сцена постала сагледива ширим слојевима грађана. ${ }^{64}$ Уследио је и развој школског система, од чега су посебно мањине имале велике користи. На овај начин танзиматски либерализам охрабривао је очување идентитета националних елемената који су Османско царство чинили, али је тиме код њих индиректно подстицао и сецесионистичке амбиције, које су посебно биле видљиве на Балкану. ${ }^{65}$

Са Србијом су ствари стајале другачије. Како је језгро српске земље формално било полузависно од османског политичког утицаја, постојала је опасност од подривања османског поретка преко подршке Србије српском народу у Румелији. Због тога су пограничне османске власти биле ванредно подозриве према свему што је долазило из ње. Овакво стање лако се могло пратити на основу прилика у Нишу.

Уочи Мидхат-пашиног доласка у Ниш, српска влада уредбама је наредила замену фесова сељачким вуненим капама, чиме је показала решеност да раскине са оријенталним наслеђем на својој територији. ${ }^{66}$ Поред тога, 1863. године стари Лицеј је реорганизован као Велика школа, чиме се образовање чиновничког и просветарског кадра убрзало. Ово је било посебно незгодно за власти у Нишу, пошто им се од четрдесетих година XIX века све већи број дипломаца из Србије обраћао

у преводу пашине биографије. У вези са склапањем брака код хришћана, стоји само да су укинути неки штетни и назадни обичаји, међу осталима и претерани трошкови око женидбе, међутим, није јасно да ли је ово значило и да се, под пашиним притиском, мењао рад институција задужених за ово, као што је црква, тј. Нишка епископија (у случају црквено склопљених бракова) или рад нишке мехћеме (у случају грађанских бракова), с обзиром на то да је још у XVIII веку био висок проценат бракова које су нишки хришћани склапали пред кадијом.

${ }^{64}$ Р. Мантран, Историја Османског цуарства, 561.

${ }^{65}$ Р. М. Петковић, Учитељска школа у Нишу, Нишки зборник 2 (1976) 52. Грчке школе на територији Османског царства могле су да примењују актуелни грчки закон о организовању школа обнародован 18. фебруара 1843. године.

${ }^{66}$ М. Екмечић, Дуго кретағе између клаға и орања. Историја Срба у Новом веку (1492-1992), Београд 2007, 203. 
за учитељску службу у Нишу. Већина Мидхат-пашиних претходника није имала дефинисан став према њима, као што није имала ни према образовању локалних хришћана. Међутим, Мидхат-паша је као један од најобразованијих Османлија тог доба имао префињенији приступ овом питању.

У вези са хришћанским школама у Нишу, пашу је највише бринуо локални бунтовнички елеменат који је кроз њих могао да легализује своју завереничку делатност. Као вођа једне такве групе означен је био учитељ Атанасије Петровић Таса. Учитељ Таса стекао је велики углед међу Србима у Нишу кријумчарећи књиге из Србије. Зато је Мидхат-паша посебно водио рачуна о контроли рада хришћанске школе у којој је Таса предавао, сумњајући да је складиште шверцованих књига. Стицајем чудних околности, у ноћи уочи најављене пашине посете школи где је учитељ Таса радио, избио је пожар који је школу уништио до темеља ${ }^{67}$ Истрага није дала доказе о Тасиној умешаности, те је била прекинута. ${ }^{68}$

Нестанком ове школе највише штете претрпели су њени ученици, пошто је у наредне две године настава за њих организована по хановима и механама. Тек 1863. године Мидхат-паша покреће иницијативу за завршетак једног већег грађевинског подухвата, на који се изградња нове школе надовезала. Реч је о изградњи Саборног храма, у чијој је порти планирано да буде смештена нова хришћанска школа. ${ }^{69}$

У прикупљању средстава за изградњу школе и наставак радова на Саборном храму Мидхат-паша је лично био ангажован. Осим што је окупио нишке чорбаџије и затражио од њих донације, лично је приложио 2.000 куруша за предстојеће радове. Пашин пример следио је и епископ Ниша Калиник, који је приложио своту мању за један куруш, како не би увредио пашу. ${ }^{70}$

Школа је подигнута заједно са Саборним храмом у палилулској махали (1864). Заједно са старом, укопаном Црквом Светих арханђела Михаила и Гаврила и новим Саборним храмом чинила је саставни део нишког духовног средишта. Поред наставе, у њој су одржавани испити и прославе на којима су присуствовали свештеници, чорбаџије и са̂м паша.

\footnotetext{
${ }^{67}$ М. Ристић, Историја града Ниша, 111.

${ }^{68}$ Р. Стојановић, Утемељивач нишке просвете и препород српске школе, Нишки весник 2 (2000) 2.

${ }^{69}$ М. Милићевић, Краљевина Србија, 163.

${ }^{70}$ Народни музеј Ниш, библиотека, рукопис 834. М. Рашић, Из прошлости Ниша, 1958, 5 (= НмН, Из прошлости Ниша).
} 
Милан Ранђеловић

Школа је била стабилна, једноспратна зграда, али са пуно дрвених елемената због чега је имала озбиљних грађевинских мана. ${ }^{71}$ И поред тога, важила је за једно од најлепших здања у Нишу, те је након ослобођења 1878. године у њој била одржана прва српска скупштина у новоослобођеним крајевима.

\section{Саборни храм и црквене прилике}

Саборни храм у Нишу настао је као исход тактизирања којим су тројица нишких епископа наступали пред османским властима. За време изградње храма главни проблеми са којима су се нишки епископи носили било је мњење муслимана у граду, променљив став актуелног паше, као и његов личан став о правима хришћана потврђених хатихумајуном 1856. године. Иако се поједине нишке паше нису слагале са оним што је хатихумајун прокламовао, морали су да воде толерантну политику према немуслиманским заједницама у Нишу, јер је са Порте очекивано од њих да поред политике реда спроводе и ефикасну пореску управу над хришћанима. У пракси, то је значило да су поједини управници Ниша морали да левитирају између личног конзервативног става, који су делили са већином муслимана у Нишу према немуслиманима, и спровођења државне политике толеранције. Ово последње, иако на штету муслимана, често је за управнике Ниша било лукративно, пошто су на уступке немуслиманским милетима, посебно хришћанима, били подстицани митом од локалних чорбаџија и епископа. Са тако осигураном подршком, изградња Саборног храма у Нишу је и почела 1856. године. ${ }^{72}$

Однос Мидхат-паше и тадашњег епископа Ниша Калиника био је растерећен било каквог превирања између њих двојице. Стару, урушену Цркву Светог Николе под Горицом, која је још у XVIII преобраћена у џамију, паша је обновио као богомољу за потребе мухаџира досељених из Београда у Ниш након 1862. године. Хришћанске артефакте (икона Св. Николе и један путир) који су нађени током ових радова он је уредно предао епископу Калинику. ${ }^{73}$ Тек након што се обновом ове цркве-џамије осигурао од притужби муслимана, Мидхат-паша је могао да се ангажује у вези са наставком изградње Саборног храма.

71 Т. Јовановић, Прве седнице скупштине кнежевине Србије у ослобођеном Нииу 1878. године, Зборник историјских музеја Србије 27 (1993) 31.

${ }^{72}$ С. Новаковић, Свети Симеон у Нишу, Српске новине (23. фебруар 1878) 174.

${ }^{73}$ Споменица нишке Саборне иркве, Ниш 1894, 9 (Стев.). 
Колико год био далековид, Мидхат-паша није правилно проценио вредност нишког Саборног храма, пошто је несвесно помогао изградњу највеће српске цркве до изградње Храма Светог Саве у Београду. ${ }^{74}$

\section{Закључак}

Након одласка Мидхат-паше са службе у Нишу, приметно је било замирање скоро свих јавних радова који су у његово време започети. Због све сложенијег политичког стања у Османском царству, као и тешке економске ситуације, потоњи управници Ниша нису много чинили за унапређење града, тако да је делатност Мидхат-паше засенила мандате већине њих.

Анализом улоге коју је Ниш имао у Мидхат-пашином политичком животу, као и искустава која је на наредним постављењима из њега пренео, јасно је да је од самог доласка у Ниш имао намере да га искористи у експерименталне сврхе. С тим у вези, он је тестирао реформне подухвате ранијих танзиматских модернизатора и остварио део пројектних идеја које је видео током својих пропутовања по Западној Европи. На тај начин, у пограничном граду какав је био Ниш, њему је пошло за руком да створи османску верзију идеалне утопије која га, нажалост, није надживела.

Шира слика Мидхат-пашиних достигнућа у Нишу указује да је Србији оставио град који ће по ослобођењу 1878. године имати добре основе за даљу модернизацију. Та модернизација од стране нових српских власти ишла је путем европеизације овог града, у чему су се врло брзо изгубили сви резултати рада овог османског управника.

${ }^{74}$ М. Милићевић, Краљевина Србија, 103. 


\section{ЛИСТА РЕФЕРЕНЦИ - LIST OF REFERENCES}

\section{Архиви - Archives}

Историјски архив Ниш, Старе и ретке књиге, Мидхат-пашини мемоари (превод Оријенталног института, документ без сигнатуре), Сарајево 1953. [Istorijski arhiv Niš, Stare i retke knjige, Midhat-pašini memoari (prevod Orijentalnog instituta, dokument bez signature), Sarajevo 1953]

Народни музеј Ниш, библиотека, рукопис 834. Рашић М., Из прошлости Нища, 1958. [Narodni muzej Niš, biblioteka, rukopis 834. Rašić M., Iz prošlosti Niša, 1958]

\section{Извори - Primary Sources}

Ђорђевић В., Успомене, прир. С. Слапшек, Београд 1988. [Đorđević V., Uspomene, prir. S. Slapšek, Beograd 1988]

Живановић Ж., Ниш и нишке знаменитости, прир. Г. Максимовић, М. Ракоција, Ниш 2004. [Živanović Ž., Niš i niške znamenitosti, prir. G. Maksimović, M. Rakocija, Niš 2004]

\section{Литература - Secondary Works}

Baser V., Turkish cultural memory in Balkans. Ironic accounts of the migrations to Anatolia, Bucharest 2006.

Davison R. H., Reform in the Ottoman Empire 1856-1876, Princeton 1963.

Davison R. H., Midhat-pasha, Encyclopaedia of Islam, VI, Leiden 1991, 1031-1035.

Dursun S., Population policies of the Ottoman state in Tanzimat era: 1840-1870, Istanbul 2001. Inalcik H., Quartaert D., An Economic and Social History of the Ottoman Empire, 2, Cambridge 1994.

Midhat A. H., The life of Midhat Pasha; a record of his services, political reforms, banishment, and judicial murder, London 1903.

Somel S. A., The Modernization of Public Education in the Ottoman Empire, 1839-1908: Islamization, autocracy, and discipline, Leiden 2001.

Wink A., Al-hindi: The Making of the Indo-islamic World, 1, Leiden 1996.

Андрејевић Б., Арабаиијска компанија, Енциклопедија Ниша - историја, Ниш 1995, 10. [Andrejević B., Arabadžijska kompanija, Enciklopedija Niša - istorija, Niš 1995, 10]

Андрејевић Б., Зграда затвора-хапсане у Тврђави, Енциклопедија Ниша - историја, Ниш 1995, 84-85. [Andrejević B., Zgrada zatvora-hapsane u Tvrđavi, Enciklopedija Niša - istorija, Niš 1995, 84-85]

Андрејевић Б., Мидхат пама, Енциклопедија Ниша - историја, Ниш 1995, 155. [Andrejević B., Midhat paša, Enciklopedija Niša - istorija, Niš 1995, 155]

Андрејевић Б., Стари записи о Нишу (од V до XIX века), Ниш 1997. [Andrejević B., Stari zapisi o Nišu (od V do XIX veka), Niš 1997]

Андрејевић Б., Споменици Ниша, Ниш 2001. [Andrejević B., Spomenici Niša, Niš 2001] 
Андрејевић С., Аграрни односи и производња у околини Ниша пред ослобођење од Турака, Нишки зборник 9 (1980) 31-40. [Andrejević S., Agrarni odnosi i proizvodnja u okolini Niša pred oslobođenje od Turaka, Niški zbornik 9 (1980) 31-40]

Бакръджиева Т., На крачка пред времето. Държавникът реформатор Мидхат паша (1822-1884), Pyce 2009. [Bakrdžijeva T., Na kračka pred vremeto. Državnik't reformator Midhat paša (1822-1884), Ruse 2009]

Екмечић М., Дуго кретање између клања и орања. Историја Срба у Новом веку (14921992), Београд 2007. [Ekmečić M., Dugo kretanje između klanja i oranja. Istorija Srba u Novom veku (1492-1992), Beograd 2007]

Жупањевац М., Черкеска махала, Енциклопедија Ниша - историја, Ниш 1995, 325. [Županjevac M., Čerkeska mahala, Enciklopedija Niša - istorija, Niš 1995]

Историја Ниша, 1, Ниш 1983. [Istorija Niša, 1, Niš 1983]

Јовановић Т., Прве седнице скупштине кнежевине Србије у ослобођеном Нишу 1878. године, Зборник историјских музеја Србије 27 (1993) 27-44. [Jovanović T., Prve sednice skupštine kneževine Srbije u oslobođenom Nišu 1878. godine, Zbornik istorijskih muzeja Srbije 27 (1993) 27-44]

Каниц Ф. Ф., Срби и становништво, II, Београд 2007. [Kanic F. F., Srbi i stanovništvo, II, Beograd 2007]

Ловрић Б., Историја града Ниша, Ниш 1927. [Lovrić B., Istorija grada Niša, Niš 1927]

Мантран Р., Историја Османског изарства, Београд 2002. [Mantran R., Istorija Osmanskog carstva, Beograd 2002]

Милићеви М. Ђ., Краљевина Србија, Београд 2006. [Milićević М. Đ., Kraljevina Srbija, Beograd 2006]

Новаковић С., Свети Симеон у Нищу, Српске новине (23. фебруар 1878) 174-177. [Novaković S., Sveti Simeon u Nišu, Srpske novine (23. februar 1878) 174-177]

Ортајли И., Најдужи век империје, прир. и прев. М. Маринковић, Београд 2004. [Ortajli I., Najduži vek imperije, prir. i prev. M. Marinković, Beograd 2004]

Петковић Р. М., Учитељска школа у Нишу, Нишки зборник 2 (1976), 51-60. [Petković R. M., Učiteljska škola u Nišu, Niški zbornik 2 (1976) 51-60]

Ристић М., Историја града Ниша, 2, Београд 1934. [Ristić M., Istorija grada Niša, 2, Beo$\operatorname{grad} 1934]$

Соколовић Љ., Паре из Менафи-сандука за нишку гимназију и водовод, Нишки весник 19 (2002) 2. [Sokolović Lj., Pare iz Menafi-sanduka za nišku gimnaziju i vodovod, Niški vesnik 19 (2002) 2]

Споменица нишке Саборне иркве, Ниш 1894. [Spomenica niške Saborne crkve, Niš 1894]

Станојевић В., Историја српског војног санитета, Београд 1992. [Stanojević V., Istorija srpskog vojnog saniteta, Beograd 1992]

Стојановић Р., Утемељивач нишке просвете и препород српске школе, Нишки весник 2 (2000) 2. [Stojanović R., Utemeljivač niške prosvete i preporod srpske škole, Niški vesnik 2 (2000) 2]

Ћирић Ј., Јаркови, претече канализачије и водоводног система, Нишки весник 1 (1999) 17. [Ćirić J., Jarkovi, preteče kanalizacije i vodovodnog sistema, Niški vesnik 1 (1999) 17]

Ћирић Ј., Ислахана, Нишки весник 5 (2000) 14. [Ćirić J., Islahana, Niški vesnik 5 (2000) 14]

Царски распояжденія, Цареградскй вђстникъ (18. фебруарій 1861) 32. [Carski raspojaždenija, Caregradski vestnik (18. februarij 1861) 32]

Чубриловић В., Одабрани историјски радови, Београд 1983. [Čubrilović V., Odabrani istorijski radovi, Beograd 1983] 


\title{
Milan Ranđelović
}

\section{IMPLEMENTATION OF TANZIMAT IN NIŠ DURING THE MANDATE OF MIDHAT-PASHA IN 1861-1864}

\begin{abstract}
Summary
Although the policy of the Ottoman Empire since 1839 was the equalization of rights of all subjects, implementation of this practice in everyday life posed a lot of problems. The biggest obstacle was a centurieslong relationship among Ottoman communities based on Shari'at. This flaw in the Sanjak of Niš was most obvious in the political and economic invisibility of Christians, especially the Serbs, who were the dominant population in this part of Rumelia. With the arrival of Midhat-pasha at the head of this Sanjak, the economic systems and mechanisms of the local government that maintained such inequality were removed. Thanks to his dedicated work on this matter, the economic and political situation in Niš began to reflect the real relations among the communities in this city. The local Serbs, as the largest population of the non-Muslim community in Niš, benefited the most. By resolving most of the problems that prevented their emancipation during his mandate, Midhat-pasha unintentionally struck the foundations for the development of modern Niš, which after 1878 continued to thrive further within the Principality of Serbia.

Keywords: Ahmed Midhat-pasha, Niš, Ottoman Empire, Tanzimat, modernisation.
\end{abstract}

Чланак примљен: 18. 09. 2017.

Чланак коначно прихваћен за објављивање: 25. 05. 2018. 